\title{
UGT1A4 Gene
}

National Cancer Institute

\section{Source}

National Cancer Institute. UGT1A4 Gene. NCI Thesaurus. Code C113632.

This gene is involved in xenobiotic metabolism. 